\title{
Internet Use for Educational Purposes: Evidence from Russia
}

\author{
Irina Filippova
}

Kazan Federal University, Institute of Management, Economics and Finance, Kazan, 420008, Russia

\section{Elena Turutina}

Kazan Federal University, Kazan Law Institute of Ministry of Internal Affairs of Russian Federation

\section{Doi:10.5901/mjss.2015.v6n3p660}

\section{Abstract}

The study sets out to examine empirically the use of Internet in education process in Russia. Socio-demographic determinants of use of Internet for educational purposes, to obtain reference information or to learn the news are studied. The sample represents entire population of Russia. Significant age and gender differences in Internet use for educational purposes are discovered. Influence of satisfaction with financial status on Internet use is weak, while it is the education level of respondents which acts as the most powerful determinant of Internet use for educational purposes.

Keywords: Internet use, Internet for educational purposes, socio-demographic determinants

\section{Introduction}

Modern stage of educational development is closely linked to wide use of information and communication technologies including opportunities provided by the global Internet network. Information technologies substantially expand the opportunities to transfer teaching information. Implementation of information technologies open new prospects for all parties involved in educational activities: it makes it possible to reduce search time for information, allows for timely modernization of learning materials as well as for employment of educational programs tailored according to specific needs of trainees.

Remote access to educational resources via Internet provides for the opportunity for all participants of educational process to choose the modes of study as well as desirable levels of education. It is of particular importance for the groups of population who feel economically especially vulnerable due to widespread disproportions between supply and demand in Russian labor market $[2,3]$. Internet-based education for that matter performs an important social function: not only it might enhance the efficiency of educational process, it also to a certain extent makes it possible to mitigate the feeling of economic insecurity on the part of most vulnerable social groups, including those with lower levels of education and professional qualification as well as residents of rural areas [3,5].

However overwhelmingly extensive is the literature addressing ways and advantages of using Internet for educational purposes, corresponding empirical analysis is yet to follow. Besides, as far as the authors knowledge goes, no studies of socio-demographic determinants of use of Internet for educational purposes (the latter includes doing class assignments, obtaining required information, etc.) has been performed using Russian data.

\section{Materials and Methods}

This research is based on the longitudinal study "The Russia Longitudinal Monitoring Survey of HSE" (RLMS-HSE), which is a series of nationally representative surveys designed to monitor the effects of Russian reforms on the health and economic welfare of households and individuals in the Russian Federation. The study has been conducted by National Research University - Higher School of Economics and ZAO "Demoscope" together with Carolina Population Center, University of North Carolina at Chapel Hill and the Institute of Sociology of Russian Academy of Sciences.

Figure 1 illustrates the major ways of Internet use in education process. Most frequently the World Wide Web is used to obtain reference information and learn the news while to a much lesser extent - for educational purposes. 


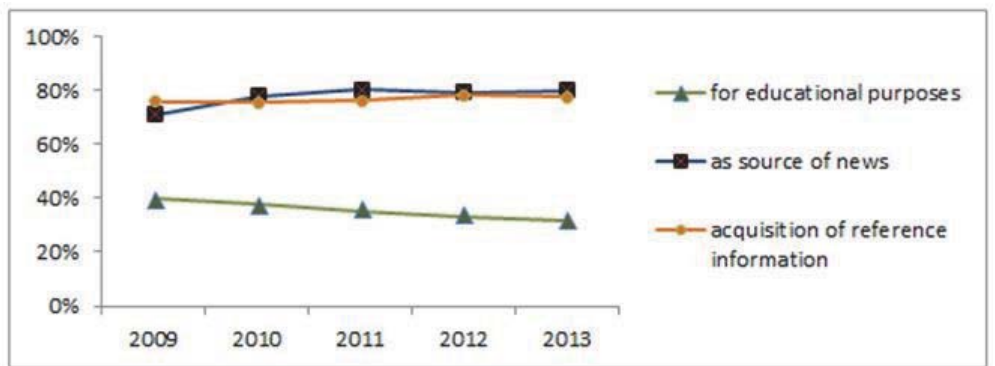

Fig. 1. Internet use for educational purposes, as percent of total number of Internet users

The binary variables used as dependent ones were formed according to respondents' answers to the following questions:

- "Have you used Internet for the 12 months?" $(1=$ yes, $0=$ no);

- $\quad$ "Have you used Internet for the last 12 months for educational purposes?" $(1=$ yes, $0=$ no);

- "Have you used Internet for the last 12 months as source of the news?" $(1=$ yes, $0=$ no);

- $\quad$ "Have you used Internet for the last 12 months to obtain reference information?" $(1=$ yes, $0=$ no);

Respondents' sex, age (quadratic form of the variable was introduced to account for possible nonlinear relationship), type of settlement they reside, satisfaction by financial status (as proxy for level of material prosperity), dummy variable of education level (with complete secondary education serving as a criterion variable) were used as independent variables.

The descriptive statistics of variables under consideration is exhibited in Table 1. The mean values presented in the table show the percentage of respondents who gave affirmative answers to the questions listed above. It has to be noted that high percentage of respondents with incomplete secondary education results from including secondary school students in the sample.

Table 1. Descriptive statistics for the year 2013

\begin{tabular}{|l|c|c|c|}
\hline Variable & Mean & Standard deviation & Number of observations \\
\hline Overall use of Internet & 0.58 & 0.49 & 19719 \\
$\ldots$ for educational purposes & 0.31 & 0.46 & 11518 \\
... as source of news & 0.79 & 0.40 & 10326 \\
... to acquire reference information & 0.77 & 0.41 & 11567 \\
Sex (1=male; 0=female) & 0.44 & 0.49 & 21753 \\
Age & 38.43 & 22.03 & 21504 \\
Age & 1962.44 & 1843.84 & 21504 \\
Incomplete secondary education & 0.20 & 0.40 & 17915 \\
Complete secondary education & 0.31 & 0.46 & 17915 \\
Vocational secondary education & 0.22 & 0.42 & 17915 \\
Higher education & 0.26 & 0.42 & 17915 \\
Large city (1=yes; 0=no) & 0.40 & 0.49 & 21753 \\
Satisfaction with financial status (1=yes; $0=n o)$ & 0.44 & 0.49 & 17651 \\
\hline
\end{tabular}

In the analysis of binary variables the appropriate technique is logit-modeling which makes it possible to estimate the probability as $\operatorname{Pr}(y=1 \mid x)=e^{x^{\prime} \beta} /\left(1+e^{x^{\prime} \beta}\right)$, where $\operatorname{Pr}$ stands for probability, $x$ is independent variables vector, $\beta$ - estimated parameters (for more details see [4]).

Estimates of logit-models' $\beta$ coefficients are obtained by maximum likelihood estimation (MLE) method. Formulae for calculation of $\beta$ and percentage change in odds can be found in [7]. All calculations and data management are performed using the software package STATA12.0.

\section{Analysis and Results}

Table 2 documents the results of logit regressions for the year 2013 data. Values of $\beta$ coefficients are not presented here for the sake of brevity since their interpretation as changes by the amount of $\beta$ in log-likelihoods is of no particular analytical value (except determination of direction the variable acts) [6]. It is percentage changes in odds that are 
analyzed.

Wald statistics allows us to reject the zero hypothesis on joint insignificance of all models' factors with high level of reliability: $p$-values for all models are less than 0.000 . Values of McFadden's $R^{2}$ indicate significant degree of statistical quality of models.

Formally interpreting the obtained logit estimates it can be noted that while the gender differences in explaining the overall access to World Wide Web are insignificant, men are approximately 19\% more likely to use Internet as source of news and 30\% less likely to use it for educational purposes as compared to women, all other factors held equal.

Table 2. Logit-regressions estimates

\begin{tabular}{|c|c|c|c|c|}
\hline Variables & $\begin{array}{l}\text { Overall use of } \\
\text { Internet }\end{array}$ & $\begin{array}{l}\text { Use of Internet for } \\
\text { educational purposes }\end{array}$ & $\begin{array}{l}\text { Use of Internet as } \\
\text { source of news }\end{array}$ & $\begin{array}{l}\text { Use of Internet to acquire } \\
\text { reference information }\end{array}$ \\
\hline Sex (1=male; 0=female) & $\begin{array}{c}-5.9 \\
(1.38)\end{array}$ & $\begin{array}{c}-29.6 \\
(6.34)^{\star \star}\end{array}$ & $\begin{array}{c}18.9 \\
(3.35)^{\star \star}\end{array}$ & $\begin{array}{c}-7.9 \\
(1.58)\end{array}$ \\
\hline Age & $\begin{array}{c}-6.6 \\
(9.27)^{\star \star}\end{array}$ & $\begin{array}{c}-31.4 \\
(34.50)^{\star \star}\end{array}$ & $\begin{array}{c}-0.3 \\
(0.25)\end{array}$ & $\begin{array}{c}-4.0 \\
(3.74)^{\star *}\end{array}$ \\
\hline $\mathrm{Age}^{2}$ & $\begin{array}{l}-0.001 \\
(5.78)^{\star *}\end{array}$ & $\begin{array}{c}0.3 \\
(28.70)^{\star *}\end{array}$ & $\begin{array}{l}-0.1 \\
(0.56)\end{array}$ & $\begin{array}{l}-0.001 \\
(1.82)\end{array}$ \\
\hline Education & & & & \\
\hline Incomplete secondary & $\begin{array}{c}-45.4 \\
(9.20)^{\star *}\end{array}$ & $\begin{array}{c}16.3 \\
(1.60)\end{array}$ & $\begin{array}{l}-30.4 \\
(4.49)^{\star *}\end{array}$ & $\begin{array}{l}-19.4 \\
(2.59)^{\star *}\end{array}$ \\
\hline Vocational secondary & $\begin{array}{c}161.6 \\
(17.10)^{\star \star}\end{array}$ & $\begin{array}{l}-6.3 \\
(0.81)\end{array}$ & $\begin{array}{c}23.2 \\
(2.97)^{\star \star}\end{array}$ & $\begin{array}{c}35.8 \\
(4.46)^{\star \star}\end{array}$ \\
\hline Higher & $\begin{array}{c}784.0 \\
(34.50)^{\star *}\end{array}$ & $\begin{array}{c}28.6 \\
(3.54)^{\star *}\end{array}$ & $\begin{array}{c}86.6 \\
(8.97)^{\star \star}\end{array}$ & $\begin{array}{c}207.6 \\
(15.36)^{\star *}\end{array}$ \\
\hline Large city (1=yes; $0=$ no) & $\begin{array}{c}112.8 \\
(16.98)^{\star \star}\end{array}$ & $\begin{array}{c}32.7 \\
(5.11)^{\star \star}\end{array}$ & $\begin{array}{c}100.1 \\
(12.97)^{\star \star}\end{array}$ & $\begin{array}{c}146.0 \\
(16.29)^{\star \star}\end{array}$ \\
\hline $\begin{array}{l}\text { Satisfaction with financial } \\
\text { status ( } 1=y e s ; 0=\text { no) }\end{array}$ & $\begin{array}{c}45.1 \\
(8.51)^{\star \star}\end{array}$ & $\begin{array}{c}20.2 \\
(3.35)^{\star \star}\end{array}$ & $\begin{array}{c}12.7 \\
(2.32)^{\star}\end{array}$ & $\begin{array}{c}17.0 \\
(3.00)^{\star \star}\end{array}$ \\
\hline Observations & 17606 & 10107 & 10161 & 10162 \\
\hline McFadden's R ${ }^{2}$ & 0.42 & 0.29 & 0.05 & 0.07 \\
\hline
\end{tabular}

Notes. The table contains results of logit-models estimates for the year 2013 data. Percentage changes in odds are presented, with t-statistics adjusted for heteroscedasticity given in parentheses. McFadden's $\mathrm{R}^{2}$ allows comparing likelihood coefficients of model incorporating only fixed term $\left(\beta_{0}\right)$ as compared to a model including all regressors.

**1\% significance level, ${ }^{\star} \%$ significance level.

Respondent's age is of substantial importance. Common trend is evident: use of Internet both in general and for educational purposes is much less likely for respondents of advanced age. This effect is especially strong for those who use Internet for educational purposes (the curve is (-shaped with increase in age) which is no wonder since it is the young who currently are most likely to be in the process of going into education. At the same time no relation is discovered between the age of respondents and use of Internet as source of news.

However, it is the education level of respondents which acts as the most powerful determinant of Internet use for educational purposes. In particular, those with university degrees are almost 9 times more likely to use World Wide Web resources in general and 3 times more likely to use it to obtain reference information. To illustrate: $784 \%$ change in likelihood means that, ceteris paribus, one positive answer of a respondent with complete secondary education (criterion variable) corresponds to 8.84 positive answers of respondents with higher education. Besides, respondents with vocational secondary education are more likely while those with incomplete secondary education are less likely use Internet both generally and to learn news or acquire reference information. At the same time no differences were established between the latter two groups as to the extent of Internet use for educational purposes.

As for other variables, respondents residing in large cities generally more widely use Internet for educational purposes. At the same time the influence of satisfaction with financial status is weak though statistically significant in all models. The latter result might indicate that for the majority of population financial limitations do not act as an important determinant of Internet use. 


\section{Conclusions}

The evidence provided by the analysis performed allows us for the following conclusions.

While the gender differences in explaining the overall use of Internet are insignificant, men $30 \%$ less frequently use it for educational purposes as compared to women.

Age of respondents does not influence their use of Internet as a source of news while use of the Web for educational purposes rapidly declines with the age of respondents. However straightforward the conclusion might seem, it is by no means insignificant since it indicates substantial degree of unwillingness on the part of population to use the most powerful tools of education including professional development programs. Under the conditions of knowledge-based economy when one's skills and qualifications get rapidly amortized it represents additional source of economic insecurity.

The so-called Matthew effect is well manifested in the influence the education level of respondents has on their use of Internet for educational purposes. However well it relates to common sense, it is a matter of great concern: those particularly vulnerable in the age of global competition are many times less inclined to use knowledge-enhancing tools most suitable for them.

Despite the straightforwardness of our results they provide objective empirical evidence in support of the measures to be taken to improve the quality of workforce and reduce vulnerability of employees with lower levels of education in case of negative economic scenario.

\section{References}

Ankudinov A.B., Lebedev O.V. Empirical analysis of employees with tertiary education occupational imbalances // American Journal of Applied Sciences. - 2013. - №10(10). - C. 1134-1139.

Cameron, A., Trivedi, P. Microeconometrics Using Stata. - Stata Press, Texas, 2009. - 732 p.

Ankudinov A.B., Lebedev O.V. Job insecurity and employees' motivation to engage in professional education // American Journal of Applied Sciences. - 2014. - №11(5). - C. 860-865.

Linz S. J., Semykina A. Perceptions of economic insecurity: Evidence from Russia //Economic Systems. - 2010. - T. 34. - №. 4. - C. 357-385.

Long, J., Freese, J. Regression Models for Categorical Dependent Variables Using Stata. - Stata Press Publication, Texas, 2001.- 311 p.

StataCorp. Stata Base Reference Manual: Release 11.0. - Stata Corporation, College Station, Texas, 2009. - 2117 p. 